\title{
Пионеры исследований толпы в зарубежной психологии: Сципион Сигеле и Анри Фурниаль
}

\author{
Дмитрий С. Горбатов ${ }^{*}$, Анна В. Байчик \\ Санкт-Петербургский государственный университет, г. Санкт-Петербург, Российская \\ Федерация \\ *E-mail: gorbatov.rus@gmail.com
}

\begin{abstract}
Аннотация
Ввеление. Указывается, что обращение С. Сигеле и А. Фурниаля, а позже и лругих исследователей, к проблематике толпы было обусловлено потребностью общества аАаптироваться к новым угрозам конца XIX в., в том числе увеличению в Ходе инАустриализации численности и активности масс пролетариата, распространению среАи них социалистических и анархистских иАей.
\end{abstract}

Теоретическое обоснование. В статье описывается солержание Авух концепций, с которых началось изучение стихийных объелинений в зарубежной психологии. Специфика толпы как социального образования, свойства толпы, фракторы ее активизации, характеристики вожаков, изменения мичности в толпе, проблема уголовной ответственности за массовые преступления - таковы основные вопросы, интересовавшие С. Сигеле и А. Фурниаля. Новизна Аанного историко-психологического исследования заключается в том, что авторами впервые прослежено зарождение тенденций чрезмерной генерализации понятия толпы, выразившейся в его некритичном распространении на целый рял социальных объединений, а также неправомерного перенесения характеристик отлельных женщин в толпе на саму толпу как субъект массового Аействия.

Результаты. Констатируется, что вылеленные тенденции наряду с отчетливо искаженным восприятием толпы, свойственным представителям антрополого-криминалистического поАхоАа, могли сыграть существенную роль в критическом отношении научного сообщества к идее об образовании новой науки, изучающей случайные и временные социальные объединения.

ОбсужАение результатов. Авторами отмечается, что отчетливый тренА современной социальной психологии стихийных объеАинений к преАпочтению изолированных когнитивных конструкций и почти полное игнорирование исслеАований прош^ого способствуют искаженному пониманию феномена толпы. Возвращение в предметное поле илей исследователей прошлых лет представ^яется оАной из необходимых преАпосы^оК А^я построения системного поАХОАव к Аанной проблематике. 


\section{КАючевые слова}

толпа, первые исследования толпы, свойства толпы, изменения ^ичности в толпе, факторы активизации толпы, вожаки толпы, женщина и толпа, преступления толпы, Сципион Сигеле, Анри Фурниаль

\section{Основные положения}

- рассмотрев специфику толпы как социального образования, ее свойства, факторы активизации, характеристики вожаков, особенности изменения Аичности в толпе, проблему уголовной ответственности за массовые преступления,

С. Сигеле и А. Фурниаль созАали предпосылки Аля развития научных представлений о Аанном френомене на периол вплоть $А$ середины XX в.;

- к числу существенных методологических ошибок Аанных исслеАователей слеАует отнести перенесение негативных черт с «преступных» на иные виды толпы, приписывание уменьшенного интелмектуального потенциала ^юбым собраниям, распространение характеристик женщин как части толпы на стихийное объеАинение в целом;

возвращение к наследию С. Сигеле, А. Фурниаля и других исследователей начального периода будет способствовать преололению тенденций чрезмерного инАивиАуализма и рационализма в современной психологии стихийных объединений.

\section{Благодарности}

Исследование выполнено при финансовой поддержке РФФИ. Проект № 18-013-00302 «Толпа и личность: историко-психологическое исследование теорий XIX - начала $\mathrm{XX}$ вв.».

\section{Для цитирования}

Горбатов Д.С., Байчик А. В. Пионеры исследований толпы в зарубежной психологии: Сципион Сигеле и Анри Фурниаль // Российский психологический журнал. 2018. Т. 15, № 2. C. 8-25. DOI: 10.21702/rpj.2018.2.1 


\title{
Pioneers in the Study of Crowds in European Psychological Research: Scipio Sighele and Henry Fournial
}

\section{Dmitry S. Gorbatov", Anna V. Baychik}

Saint Petersburg State University, St. Petersburg, Russian Federation

*Corresponding author. E-mail: gorbatov.rus@gmail.com

\begin{abstract}
Introduction. By the end of the 19th century the society had to adapt to new threats namely, the increase in numbers and activity of the proletariat masses and the wide spread of socialist and anarchist ideas. Subsequently, many researchers concentrated their study on characteristics of crowds. Scipio Sighele and Henry Fournial were pioneers in this field. Theoretical Basis. The paper describes two concepts whose introduction started studying crowds in European psychological research. Among the main issues considered by Scipio Sighele and Henry Fournial were: characteristics of the crowd as a social institution, its properties, activation factors, characteristics of leaders, personality changes within the crowd, and the problem of criminal liability for mass crimes. The paper presents an innovative view of the origins of the excessive generalization of the 'crowd' concept, which manifested itself in its uncritical acceptance for defining a number of social associations, as well as wrongfully attributing characteristics of individual women to the crowd as the subject of mass actions.
\end{abstract}

Results. The paper ascertains that representatives of the anthropological and criminological approach maintain a clearly distorted perception of crowds, which might have determined the critical attitude towards new science of random and temporary social associations.

Discussion. A distinct trend towards isolated cognitive constructs and almost complete disregard for the past research inevitably contribute to a distorted understanding of the 'crowd' phenomenon in modern social psychology of spontaneous groups and associations. Revisiting and reintegrating the ideas of researchers of the past seem to be a necessary precondition for developing a holistic approach to this problem.

\section{Keywords}

crowd, first studies of crowds, crowd properties, personality changes, crowd activation factors, crowd leaders, crowd and woman, crowd crimes, Scipio Sighele, Henry Fournial

\section{Highlights}

- S. Sighele and H. Fournial formed a foundation for scientific understanding of the phenomenon of crowds until the mid 20th century. They considered specific characteristics of the crowd as a social entity, its properties, activation factors, 


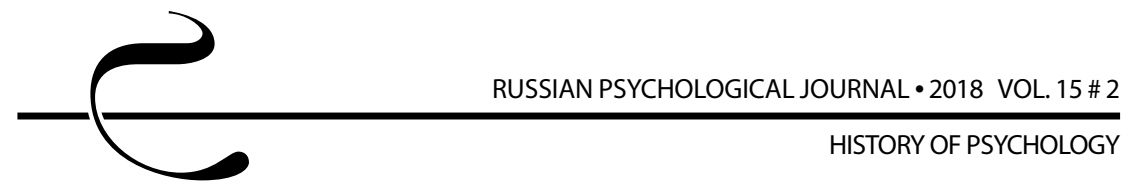

characteristics of leaders, personality changes within crowds, the problem of criminal responsibility for mass crimes.

- Methodological weaknesses in S. Sighele's and H. Fournial's studies included: (a) attributing negative traits of criminal crowds to other crowd types; (b) ascribing a reduced intellectual potential to any sizable social gathering; and (c) attaching characteristics of women in a crowd to the crowd as the subject of mass actions.

- The heritage of S. Sighele, H. Fournial, and other researchers of the earlier period can help in overcoming excessive individualism and rationalism of the modern psychology of spontaneous social associations.

\section{Acknowledgments}

This research received funding from the Russian Foundation for Basic Research for a study on Crowds and Personality: A Historical and Psychological Study of the Theories in the 19th and early 20th centuries, project no. 18-013-00302.

\section{For citation}

Gorbatov D. S., Baychik A.V. Pioneers in the Study of Crowds in European Psychological Research: Scipio Sighele and Henry Fournial. Rossiiskii psikhologicheskii zhurnal - Russian Psychological Journal, 2018, V. 15, no. 2, pp. 8-25 (in Russian). DOI: 10.21702/rpj.2018.2.1

Original manuscript received 05.03.2018

\section{Введение}

Изучение психологической природы толпы в западноевропейской науке началось с 90-х гг. XIX века. Основой для этого послужили во многом правдоподобные, проницательные и подчас парадоксальные интерпретации поведения стихийных объединений, встречавшиеся на страницах трудов исторической, социально-философской, медицинской, естественнонаучной и политической проблематики. Однако представители разных слоев образованного общества, обеспокоенные индустриализацией, сопровождаемой увеличением численности и активности пролетарских масс, распространением социалистических и анархистских идей, помнившие недавние времена Парижской коммуны, уже не могли удовлетвориться разрозненными наблюдениями и комментариями относительно буйства народной стихии.

Если в России публикация по уличной толпе публициста и литературного критика Н.К. Михайловского [1] появилась еще в 1882 г., то для западного читателя этот феномен впервые получил относительно целостное отражение в небольшой анонимной заметке в британском медицинском журнале «Lancet» (1886 г.), перепечатанной с сокращениями парижской газетой «Le Temps» [2]. Подлинными пионерами зарубежных исследований толпы 
выступили - в Италии начинающий юрист С. Сигеле (1891 г.), а во Франции будущий военный врач, энтузиаст судебной медицины А. Фурниаль (1892 г.).

Анализ природы стихийных объединений рассматривался ими как предпосылка к решению вопросов сугубо юридического свойства - о степени вменяемости, вины и ответственности за массовые преступления. Оба исследователя являлись приверженцами нового для того времени антрополого-криминалистического подхода позитивистской ориентации, предусматривавшего отказ от отвлеченных рассуждений о преступных деяниях в пользу естественнонаучного изучения самих преступников в совокупности их биологических, физиологических, психических черт [3]. При этом они принадлежали к конкурирующим направлениям. С. Сигеле разделял теорию Чезаре Ломброзо (Lombroso) о существовании заведомо неисправимых «прирожденных преступников», выделяющихся атавистической телесной конституцией и ущербной психической организацией. А. Фурниаль мыслил в русле идей Александра Лакассаня (Lacassagne), подчеркивавшего роль социальной среды как «питательного бульона» для дремлющих душевных аномалий [4].

Рассмотрим содержание вклада данных исследователей в понимание стихийных объединений, сложившееся к началу XX в., а также то, насколько их воззрения представляют интерес с позиций сегодняшнего дня.

\section{Теоретическое обоснование}

\section{Первые исследователи толпы}

Сципион Сигеле (1868-1913), потомственный законовед, начинающий преподаватель уголовного права, активнейший участник ирредентистского движения, добивавшегося возвращения территорий с преобладанием итальянского населения, опубликовал первое издание книги «Преступная толпа. Опыт коллективной психологии» [5] сразу после получения ученой степени в римском университете. В скором времени появились ее переводы на французский, немецкий, английский, русский, испанский, польский языки [6]. Ни одна из последующих работ ученого, в том числе посвященных той же проблематике, не приобрела такой популярности. Несомненно ее влияние на восприятие толпы Г. Лебоном [7], Г. Тардом [8], П. Росси [9], Э.А. Россом [10], а также российскими исследователями Д.Д. Безсоновым, В.М. Бехтеревым, Л.Н. Войтоловским, В. К. Случевским и мн. др. [11].

Анри Фурниалю (1866-1932) книга о толпе, напротив, не принесла особого признания и не обеспечила академической карьеры, и он почти сразу пропал из поля зрения научной общественности [12]. В большинстве современных трудов по данной проблематике его имя без рассмотрения идей по существу помещается в конце списка более известных исследователей того времени. Показательно, что при этом автора иногда поспешно характеризуют как 


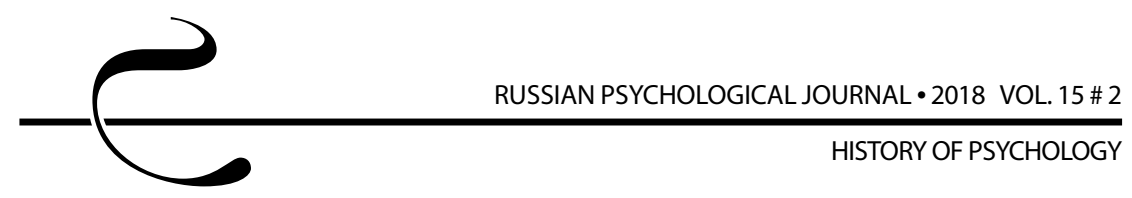

криминалиста [13], психолога [4], начинающего антрополога [14]. Однако из биографии А. Фурниаля [15] мы узнаем, что будущий ветеран многих колониальных конфликтов Третьей республики и мировой войны, закончивший службу в генеральской должности главного медицинского инспектора, в дальнейшем великий офицер (grand officier) Почетного легиона в 1891 г. окончил двухлетний курс военно-санитарной школы в Лионе. «Очерк по психологии толпы: медико-правовое рассмотрение коллективной ответственности» [16] стал его выпускной квалификационной работой, выполненной под руководством главы французской школы судебной медицины и криминальной антропологии профессора А. Лакассаня. Уже в январе 1892 г., учитывая интерес широкой публики к феномену толпы, издатели опубликовали ее сразу в Лионе и в Париже.

С. Сигеле резко охарактеризовал работу новоиспеченного военного врача как «истинное литературное пиратство» [17, с. 39]. Однако для этого нет оснований. В отличие от Г. Лебона, зачастую синтезировавшего чужие идеи без указаний авторства [18], А. Фурниаль многократно ссылался на итальянского предшественника. Анализ же тех случаев, где им при отсутствии ссылок пересказывались идеи, упомянутые или рассмотренные С. Сигеле, свидетельствует, что они последнему не принадлежат.

Во-первых, обе книги «родились на одной почве». Предельно негативный образ толпы в европейской науке сформировался под влиянием историков Великой французской революции А. Ламартина, Ж. Мишле, И. Тэна, А. Тьера, мемуаров современников, литераторов В. Гюго, Э. Золя, Г. де Мопассана, А. Мандзони, социальных философов Ж. де Местра, М. Нордау и др. Даже те из них, кто поддался очарованию идей или творцов бурных событий, неизменно описывали беспощадность и слепость человеческой стихии, рисовали толпу как чудовище, которое, будучи разбуженным, не заснет вновь, пока не пресытится преступлением. В подобной метафоричности, по замечанию С. Бэрроуз [18], проявилась коллективная рационализация страхов политической, экономической, культурной и научной элиты конца XIX в. перед необратимыми социальными изменениями.

Во-вторых, весьма схожа была логика доказательств. Действуя в духе доктрины позитивизма, тот и другой автор пытались обосновать свои ключевые положения ссылками на специалистов в области физиологии, психиатрии, криминальной статистики, гипнотизма. Однако недостаточность данных этих наук вынуждала их чаще прибегать к иллюстрирующим примерам, заимствованным из работ историков, литераторов, моралистов. В силу невольной аберрации сознания, свойственной антропологам-криминалистам, многие из подобранных примеров отличались заведомой односторонностью. Так, каждый из них не преминул описать линчевание взбунтовавшимися 
рабочими инженера Ватрена в 1886 г. Однако известно, что в тот период насильственные действия сопровождали не более чем десятую часть массовых уличных шествий и лишь четыре процента от общего числа забастовок [19].

В-третьих, следует учесть и то, что при интерпретации глубинных процессов, происходящих в толпе, С. Сигеле и А. Фурниаль видели одно и то же, в равной мере опираясь на теорию подражания Г. Тарда [20]. Согласно основателю психологического направления в социологии, роль, подобная той, которую в биологии выполняет наследственность, а в физике - молекулярное движение, во всех аспектах социальной жизни принадлежит непрерывному копированию поведения, суждений, образа жизни, технологий, верований и желаний. Тотальность для социума и имманентность для личности, приписываемые этому феномену Г. Тардом, придавали даже «изобретению» тесную связь с подражанием. Если «общество - это подражание» [20, с. 74], то иные механизмы социального влияния в толпе принимали по отношению к нему однозначно подчиненный характер. Внушение, известное по трудам гипнологов, становилось одним из возможных условий подражания, а эмоциональное, моральное и ментальное заражение, описанное психиатрами того времени [2], - его следствием. Соответственно, когда С. Сигеле предпочитал говорить о подражании и внушении, а А. Фурниаль - о подражании и заражении, для читателей разница оказывалась несущественной.

\section{Толпа как объект научного изучения}

Выделение толпы в качестве нового объекта исследований, прежде всего, предполагало указание на признаки, отличающие ее от разрозненного множества лиц, связанных лишь местом и временем присутствия. По А. Фурниалю, появление толпы способно вызвать любое событие, поражающее восприятие внезапностью или интенсивностью. Возникающее индивидуальное возбуждение требует обмена с окружающими впечатлениями, мыслями и переживаниями. Тогда в силу подражания и зарождается «безликое существо», на основе общих чувств и идей сплавляющее воедино прежде разрозненные индивидуальности. Толпа начинает думать и действовать как один человек. Согласно С. Сигеле, степень отождествления личностей при этом становится столь велика, что новообразование допустимо именовать как «душа толпы».

Каковы ее свойства? Используя представления своего учителя о трех типах преступников, различающихся сравнительной активностью частей мозга, А. Фурниаль писал, что толпа «затылочная, теменная, но никогда не лобная» [16, с. 23]. Иначе говоря, она способна с пугающей интенсивностью чувствовать и действовать, но не рассуждать. При этом толпа нередко бывает опасна, но не всегда злонамеренна. С точки зрения С. Сигеле, социальное объединение самым пагубным образом действует на добрые чувства: «толпа - это 


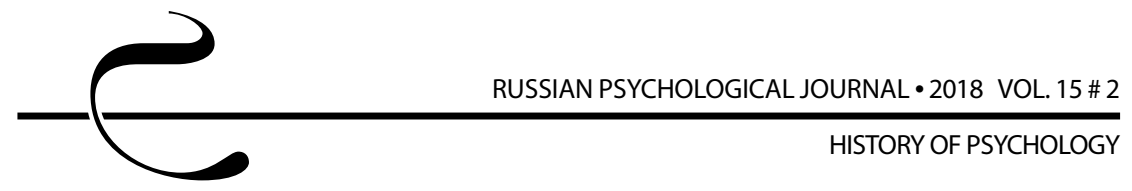

субстрат, в котором микроб зла развивается очень легко, тогда как микроб добра умирает почти всегда, не найдя подходящих условий жизни» [5, с. 42].

По его мнению, тому множество причин:

- злоба, стремление нанести вред другим, более активна по своей природе, чем пассивное добродушие, неделание никому зла;

- те, кто активно добры, наталкиваются на превратное истолкование мотивов, слышат обвинения в трусости, предательстве и часто отступают под угрозой санкций;

- восприятие выражений гнева через выражение лиц, энергии жестов, интонации возгласов одних усиливает аналогичные эмоции у других;

- принявшие вид разгневанных и ожесточенных исключительно из соображений внешней подстройки под окружающих, начинают переживать эти чувства, т. к. реальные душевные состояния тесно связаны с их внешними выражениями;

- «нравственное опьянение», при котором пропорционально численности в толпе усиливаются до абсолюта чувства могущества и безнаказанности;

- атавистический «кровавый инстинкт», опьянение кровью, криками жертв, выстрелами, звуками разрушений;

- чрезмерное количество алкоголя;

- ожесточенность бедноты, составляющей большинство уличных толп, из-за своего социально-экономического положения;

- влияние на толпу вожаков, портрет которых рисовался темными красками: «преступники, умалишенные, дети умалишенных, алкоголики, вообще социальная грязь, лишенная всякого нравственного чувства и развращенная преступлением, - составляли самую главную часть бунтовщиков и революционеров. Примешайте к легкомысленной и повинующейся всякому толчку толпе этих личностей, - они и сообщат ей ее жестокость и сумасшествие» [5, с. 69-70].

С. Сигеле допускал, что проявления самоотречения, добродетели, героизма возможны в толпе под влиянием отдельных вожаков, но встречаются чрезвычайно редко. Скорее, ее непостоянство будет принято неискушенным наблюдателем за милосердие, а жестокость - за смелость. Зато в том, что касается состояния интеллекта толпы, итальянский исследователь был категоричен. Более того, вслед за писателем А. Габелли и философом М. Нордау он считал, что любое собрание - суд присяжных, парламентская ассамблея, научный совет или художественная комиссия - способны выдать решения нелепые и бессмысленные, уступая по интеллектуальным характеристикам любому из своих членов. Позже в книге «Интеллект толпы» С. Сигеле дал методологически неосновательное объяснение, в частности, ссылаясь на то, что интеллект отличается от чувств отсутствием адекватного внешнего 
выражения. Поэтому слушатели способны подняться до степени гнева, ненависти или мужества оратора, но не могут сравняться глубиной ума, да и «природе» этого не требуется: «...достаточно, чтобы был гений, но недостаточно, чтобы только один был героем. Нужен Гарибальди и тысяча героев, чтобы выиграть сражение. Тысяча Гарибальди бесполезна» [21, с. 11]. Заметим, что и Г. Тард оказался в этом вопросе не чужд поверхностным умозаключениям, полагая, что собрание почти всегда уступает индивиду, т. к. по сложности и эластичности своей структуры не сравнится с устройством мозга, «этой несравненной армии нервных клеточек, которую каждый из нас носит в своей голове. Хорошо сотворенный ум стоит выше парламента» [22, с. 352].

Этот тезис позже сыграл определенную роль в чрезмерной генерализации Г. Лебоном [7], Л.Н. Войтоловским [23] и др. понятия толпы, его некритичном распространении на иные объединения - от политических и религиозных сект до социальных классов. Вызвал он и многочисленную критику с позиций несоответствия обоснований элементарному здравому смыслу [11].

Надо сказать, что, в отличие от А. Фурниаля, С. Сигеле проявлял заметную склонность к некорректным обобщениям, формулируя то «роковой арифметический закон психологии» - нивелировки личности до среднего уровня собравшихся, то «закон психического мимизма» - склонности вести себя как окружающие, то «неоспоримый психологический закон» возрастания интенсивности душевного движения пропорционально числу присутствующих. Каких-либо границ действия таких «законов» при этом не оговаривалось. Своеобразна была и аргументация: помимо ссылок на труды ученых или литераторов, он подчас писал, что «это известно всякому и доказывать это бесполезно» [5, с. 13], «всякий знает по опыту, насколько это справедливо» [5, с. 67] и проч.

Особый интерес исследователей вызвали факторы активизации толпы. В частности, А. Фурниаль указал на возможные факторы физические (степень жары, количество солнечного света, звуки музыки, фазы луны, атмосферное давление, магнитные бури), химические (спертость воздуха, избыток или недостаток влаги, особенности почвы (?), питания, злоупотребление алкоголем), индивидуальные (возраст, пол, наследственность), социологические (влияние городской жизни). Следует отметить, что последней категории не было уделено достаточного внимания: по сути, начинающий ученый ограничился суждением, что она существует. По утверждению И.И. Добровольского [24], критика пионеров исследований толпы, С. Сигеле в первом итальянском издании также проигнорировал социальные факторы, лишь позже внеся некоторые коррективы.

Автор «Преступной толпы» в первую очередь сосредоточился на факторах антропологических, имея в виду специфичность состава стихийных 
объединений: «толпа хороших людей может пойти по дурной дороге, но она никогда не дойдет до той степени испорченности, до какой может дойти толпа дурных людей» [5, с. 81]. К последним были отнесены «прирожденные» преступники («профессиональные», по терминологии осторожного А. Фурниаля), лица, привыкшие к крови в силу избранного рода занятий, а также сумасшедшие и социальные деграданты. Верховенство одних придает толпе жестокость, а других - непредсказуемость. Если же она состоит из людей безупречного прошлого, добросовестных и работящих, то все буйство может ограничиться лишь угрозами, криками, незначительными разрушениями.

Однако гарантии того, что вред от «антропологически хорошей» толпы минимален, исследователи дать не могли. Дело в том, что они разделяли концепцию Ч. Ломброзо об атавистических инстинктах первобытного зверя, скрытых в глубинах всякой души под слоями цивилизации и способных вырваться наружу при непредвиденном случае. А. Фурниаль предупреждал: «... опасно сплочение людей в толпу. Обществу следует ожидать, скорее, взрыва дурных инстинктов, чем добрых чувств. Из толпы... чаще всего вырастает "человек-зверь"» [16, с. 109].

Подобные рассуждения представлялись И.И. Добровольскому в корне неверными. По его ироничному замечанию, доктрина атавизма служит ученым ровно в том качестве, что «лукавый» темному невежественному народу. И если простой мужик обычно объясняет грех словами «лукавый попутал», то антрополог-криминалист при виде преступления утверждает: «дикий зверь проснулся» [24, с. 155-156]. Профессиональному революционеру казалось очевидным, что социальные условия важнее антропологического состава, т. к. определяют те чувства, настроения и идеи, что вносят в толпу ее истощенные эксплуатацией единицы.

Анализируя представления создателей первых теорий толпы об активизации в ней животного начала, К. Галлини [6] своеобразно конкретизировала «видовую принадлежность» получившегося монстра. С одной стороны, исследователи описывали толпу как неистового и неконтролируемого «волка», а с другой - подразумевали под ней стадную и пассивную «овцу». И когда «овца» испытывала возбуждение, она превращалась в «волка», для которого уже не существовало пастыря. Набор метафор был бы неполон, если бы К. Галлини не заимствовала у А. Фурниаля образ «гиены», отталкивающей, пугливой и беспредельно жестокой, для обозначения той роли, которую приписывали женщине в толпе.

В рассуждениях С. Сигеле и А. Фурниаля об «особой» роли женщины явственно проявились гендерные стереотипы. К примеру, когда авторы описывали преступление мужчины в толпе, они ссылались на принадлежность того к категории прирожденных или профессиональных преступников, 
подчеркивали специфичность профессии или отмечали роль сумасшествия. Если же преступление совершалось женщиной, половая принадлежность рассматривалась ими на правах «все объясняющего» обстоятельства, не нуждающегося в дальнейшей конкретизации.

Как следствие, в психике женщины первые исследователи толпы находили черты, обусловливающие колоссальную податливость внушению и заражению, описывая восприимчивость сторонним влияниям, впечатлительность, переменчивость, силу воображения и слабость воли. Попав под влияние толпы, она, якобы, меняется до неузнаваемости: «когда женщина опьянеет от крови, она не знает ни границ, ни меры, ...если женщина жестока, она в то же время и храбра» [5, с. 70].

Интересно, что вскоре Г. Лебон [7], Г. Тард [22] и др. сочли допустимым перенести характеристики психики и поведения женщин в толпе на саму толпу в целом. И С. Сигеле позже писал: «толпа как женщина - ее психология экстремальна, способна на любые эксцессы, может быть, способна только на эксцессы, она поразительна в самоотречении, часто пугающе жестока и почти никогда не рассудительна и не уравновешена в своих чувствах» [21, с. 4]. Кульминацией обозначившейся тенденции стала работа [25], в которой обобщенный портрет женщины и образ толпы были очерчены чрезвычайно мрачными, но удивительно похожими красками так, что местами читателю нелегко понять, идет ли речь о женщине или о толпе.

Почему слабые натуры не способны устоять перед вожаками? Ответ первых исследователей толпы не отличался оригинальностью. Все они от Н.К. Михайловского до Г. Лебона - ссылались на наличие у тех обаяния (фр. «prestige»), понятия, заимствованного из работ французских психиатров и гипнологов 70-х гг. XIX в. [2] и позже подкрепленного авторитетом Г. Тарда [20]. Если С. Сигеле ограничился на этот счет несколькими цитатами, то А. Фурниаль рассмотрел составляющие обаяния, правда, на примере исторических личностей, а не вожаков толпы. При этом он не отделял личностные качества от поведенческих проявлений, представив в одном ряду честолюбивый характер, незаурядную энергию, неукротимую гордость, интенсивность желаний, решительность речей, громогласность голоса, повелительность жестов, меткость фраз, способность удивлять, умение воодушевлять, воздействовать на воображение и проч. Представляется вполне вероятным влияние его соображений на П. Росси [9] и Г. Лебона [7], а через посредничество последнего - на становление в начале XX в. психологии лидерства.

\section{Проблема ответственности за массовые преступления}

Пионеры исследований толпы считали оправданным наказание вожаков по всей строгости закона. Согласно Г. Тарду [22], фактически, тем самым они 
игнорировали интенсивность процессов взаимного внушения и интенсивного заражения, способных превратить, к примеру, первоначально умеренные призывы в кровопролитные действия. Поэтому далеко не всегда, по его мнению, было бы справедливо назначать вожаков ответственными за все без исключения преступления распалившейся толпы. Перефразируя С. Сигеле, согласимся с тем, что они сами могли оказаться потерпевшими кораблекрушение от вызванной ими же «психологической бури». Однако осознание общественной опасности стихийных объединений подталкивало С. Сигеле и А. Фурниаля к юридически простым, но психологически неоднозначным решениям.

В отношении всех остальных, ведомых вожаками, итальянский правовед признавал трудности установления степени вины за массовые преступления. Как комментировал В.К. Случевский [26], несложно осудить, к примеру, лиц, разрушивших здание, но не всегда очевидна вина тех, кто вовремя снабдил их подходящим инструментом, уничтожил отнесенный в сторону материал, пытался воспрепятствовать усилиям правоохранителей или ограничился словесным одобрением происходящего. Если А. Фурниаль оставлял содержание вердиктов о ведомых на усмотрение судов, видя свою задачу лишь в информировании о психологической специфике толпы, то С. Сигеле склонялся к мнению тех, кто допускал половинную ответственность за участие в массовых преступлениях. Обоснованием подобного компромисса стало рассмотрение им взглядов представителей нансийской (А.О. Льебо, Ж.Ж. Льежуа, А.Э. Бони) и сальпетриерской (Ж.М. Шарко, П.К. Бруардель, Дж.Р. Дельбеф и др.) школ гипнологии на возможность преодоления нравственных норм личности в состоянии гипноза. По итогам дискуссии он сделал вывод о том, что внушение не способно побудить человека к совершению поступков, к которым он не имеет никакой предрасположенности. Соответственно, даже самое мощное влияние толпы априори не превращает его, как безапелляционно утверждал позже Г. Лебон [7], в пассивный бессознательный автомат, у которого больше не существует собственной воли и нравственного стержня.

Заметим, что А. Фурниаль различал в структуре толпы, помимо вожаков и ведомых, еще одну категорию лиц - наблюдателей, тех, кто присутствует на месте событий, но не принимает в них участия. По отношению к ним не описывалось вариантов юридических действий. Однако определенная необходимость в этом была: само их присутствие, зрительно увеличивавшее для толпы ее численность, тем самым усиливало чувства могущества и безнаказанности [27].

Новизна исследуемой области не позволяла создателям первых концепций толпы обстоятельно описать юридические перспективы, вытекающие из очерченной ими в изначальном приближении психологической природы 
стихийных объединений. Со временем законодатели европейских стран приняли во внимание фактор психологии толпы. Однако далеко не во всех случаях они согласились с позицией исследователей этого феномена. Так, в Уголовном уложении Российской империи (1903 г.) «толпа» считалась не смягчающим, напротив, отягощающим вину обстоятельством, а ее разновидность - «скопище» - интерпретировалось в качестве некоего коллективного субъекта преступного поведения, принадлежность к которому становилась основанием для уголовного преследования [11].

\section{Результаты}

По мысли Э. Ферри, всецело поддерживаемой С. Сигеле, новая наука коллективная психология - должна была расположиться в интервале между предметными полями психологии и социологии. Если психология, по их мнению, сосредоточена на изучении индивидов, а социология - общества в целом, то коллективная психология ориентировалась на исследование случайных и временных объединений индивидов (присяжных, зрителей, парламентариев, членов толпы и проч.). Однако научное сообщество не приняло данной идеи. Существенную роль в этом могло сыграть ознакомление с первыми концепциями толпы. Мы имеем в виду наличие в них, как минимум, трех некорректных экстраполяций, а именно:

1) перенесение негативных черт, которыми представители антропологокриминалистического подхода наделяли «преступные» стихийные объединения, на иные виды толпы;

2) приписывание уменьшенного в сравнении с индивидом интеллектуального потенциала не только толпе, но и, вслед за ней, другим собраниям без исключений;

3) распространение характеристик психики и поведения женщин как части толпы на толпу в целом.

Наряду с очевидными недостатками концепций С. Сигеле и А. Фурниаля следует признать их влияние на развитие последующих исследований толпы вплоть до середины XX в. (например, на исследования Г. Блумера [28]).

\section{Обсуждение результатов}

По замечанию А. Бригенти [29], концептуальные решения, сформулированные первыми исследователями в ответ на проблемы своего времени, давно устарели, однако те вопросы, которые они порождают, и сегодня сохраняют актуальность. Это связано с тем, что современная психология стихийных объединений во многом забыла об идейном потенциале предшествовавших исследователей, почти полностью перейдя на использование объяснительных социально-когнитивных конструкций [30, 31, 32 и др.]. 
Действительно, работы ученых прошлого нередко отличали непоследовательность и запутанность изложения материала, неоперациональность ключевых формулировок, методологические упущения, игнорирование социального и ситуативного контекста, чрезмерная концентрация на деструктивных аспектах поведения. Однако не получилось ли так, что «вместе с водой выбросили и ребенка»? Как справедливо отметил К. Борч, в результате толпы предстали перед исследователями как общности, состоящие из отдельных рационально мыслящих и преднамеренно действующих индивидов. При реализации такого подхода, анализирующего стихийные объединения через призму когнитивной сферы их членов, «иррациональное стало рационализированным, а анормальное - нормализованным» [33, с. 85].

Обращение к наследию С. Сигеле и А. Фурниаля рассматривается нами как один из необходимых шагов по возвращению в предметное поле социальной психологии тех конструктов, которые могли бы способствовать, при их переосмыслении с позиций сегодняшнего дня, комплексному изучению феномена толпы. Это позволит преодолеть существующие тенденции к чрезмерному индивидуализму и рационализму в понимании психологической природы стихийных объединений. Таким образом, речь идет не только о дополнении имеющегося в распоряжении истории психологии массива данных в области исследований толпы, но и о создании предпосылок к поиску ответов на глобальные вызовы современности.

\section{Литература}

1. Михайловский Н. К. Герои и толпа // Сочинения: в 6 т. Т. 2. СПб.: Русское богатство, 1896. С. 95-190.

2. Aubry P. La contagion du meurte. Étude d'anthropologie criminelle. Paris: Félix Alcan, Éditeur, 1888. 184 p.

3. Вульферт А. Антрополого-позитивная школа уголовного права в Италии: критическое исследование. Вып. 1. М.: Тип. В. В. Исленьева, 1887.510 с.

4. McClelland J. S. The crowd and the mob: From Plato to Canetti. London; Boston: Unwin Hyman, 1989. 343 p.

5. Сигеле С. Преступная толпа. Опыт коллективной психологии. СПб.: Изд. Ф. Павленкова, 1893. 116 с.

6. Gallini C. Scipio Sighele et la foule délinquante // Hermes. 1988. № 2. P. 105-133.

7. Лебон Г. Психология народов и масс. СПб.: Издание Ф. Павленкова, 1896. 329 c.

8. Тард Г. Преступления толпы. Казань: Издание Книжного магазина Н. Я. Башмакова, Типо-лит. Императорского университета, 1893. 44 с.

9. Rossi P. Les suggesteurs et la foule. Paris: A. Michalon, 1904. 222 p. 
10. Ross E. A. The Mob Mind // Appletons' Popular Science Monthly. 1897. Vol. 51, № 22. Р. 390-397.

11. Горбатов Д. С., Большаков С. Н. Теории толпы в российской психологической мысли конца XIX - начала XX вв. СПб.: Art-Xpress, 2015. 108 с.

12. Rubio $V$. Le regard sociologique sur la foule à la fin du XIX siècle // Mil neuf cent. Revue d'histoire intellectuelle. 2010. № 1 (28). P. 13-33.

13. Lazzeri C. La contagion des émotions entre psychologie sociale et sociologie, de Le Bon à Durkheim // Problemata: Revista Internacional de Filosofia. 2016. Vol. 7, № 3. P. 133-156. DOI: 10.7443/problemata.v7i3.32091

14. Чиркова Е. В. Анатомия финансового пузыря. М.: Кейс, 2010. 416 с.

15. Frachette C. Le Médecin-Inspecteur Général Henri Fournial (1866-1932) // Histoire des Sciences médicales. 1986. Vol. 20, № 4. P. 381-390.

16. Fournial $H$. Essai sur la psychologie des foules: considérations médicojudiciaires sur les responsabilités collectives. Lyon: A. Storck; Paris: G. Masson, $1892.113 \mathrm{p}$.

17. Sighele S. Psychologie des sectes. Paris: V. Giard \& E. Brière, 1898. 231 p.

18. Barrows $S$. Miroirs déformants. Réflexions sur la foule en France à la fin du XIXe siècle. Paris: Aubier, 1990. 226 p.

19. Bellamy $R$. The advent of the masses and the making of the modern theory of democracy // The Cambridge History of Twentieth-Century Political Thought /T. Ball, R. Bellamy (Eds.). Cambridge: Cambridge University Press, 2003. P. 70-103. DOI: $10.1017 /$ CHOL9780521563543.005

20. Тард Ж. Законы подражания. СПб.: Изд. Ф. Павленкова, 1892. 370 с.

21. Sighele S. U'intelligenza della folla. Torino: F. Bocca, 1903. 166 p.

22. Tarde G. Foules et sectes au point de vue criminel // Revue des Deux Mondes. 1893. 15 novembre. P. 349-387.

23. Войтоловский Л. Очерки коллективной психологии: в двух частях. Ч. 2. Психология общественных движений. Москва; Петроград: Гос. издательство, 1925. 118 с.

24. Д-ов И. (Добровольский И. И.) Психология «преступной» толпы // Русская мысль. 1894. Кн. 12. С. 130-158.

25. Cazanove $F$. Les femmes dans la foule: leur responsabilité criminelle. Bordeaux: Y. Cadoret, 1904. 120 p.

26. Случевский В. К. Толпа и ее психология // Книжки недели. 1893. № 5. C. $5-23$.

27. Ширков В. П. Преступления толпы по новому уголовному уложению (Конструкция ответственности) // Журнал Министерства Юстиции. 1904. № 3. C. 90-124.

28. Blumer H. Collective behavior // New Outline of the Principles of Sociology. N. Y.: Barnes \& Noble, 1951. P. 167-221. 
29. Brighenti A. M. La folla delinquente: Scipio Sighele, la psicologia delle folle e le origini della sociologia del XX secolo // Altre Storie. 2013. № 41. P. 16-18.

30. Reicher S. The Psychology of Crowd Dynamics // Blackwell Handbook of Social Psychology: Group Processes / M. A. Hogg, R. S. Tindale (Eds.). Oxford: Blackwell, 2001. P. 182-208. DOI: $10.1002 / 9780470998458$

31. Spears R., Postmes T. Group Identity, Social Influence and Collective Action Online: Extensions and Applications of the SIDE Model //The Handbook of the Psychology of Communication Technology / S. S. Sundar (Ed.). Oxford: Wiley Blackwell, 2015. P. 23-46. DOI: 10.1002/9781118426456

32. Drury J., Stott $C$. Contextualizing the crowd in contemporary social science // Contemporary Social Science. 2011. Vol. 6, Issue 3. P. 275-288. DOI: 10.1080/21582041.2011.625626

33. Borch C. The Exclusion of the Crowd: The Destiny of a Sociological Figure of the Irrational // European Journal of Social Theory. 2006. Vol. 9, Issue 1. P. 83-102. DOI: $10.1177 / 1368431006060464$

\section{References}

1. Mikhailovskii N. K. Geroi i tolpa. Sochineniya $v 6 t$ : T. 2. [Heroes and crowd. Collected works in 6 volumes:V. 2]. St. Petersburg, Russkoe bogatstvo Publ., 1896, pp. 95-190.

2. Aubry P. La contagion du meurte. Étude d'anthropologie criminelle. Paris, Félix Alcan, Éditeur, 1888. $184 \mathrm{p}$.

3. Wulfert A. Anthropological and positive school of criminal law in Italy: a critical study (Russ ed.: Vul'fert A. Antropologo-pozitivnaya shkola ugolovnogo prava v Italii: kriticheskoe issledovanie. Issue 1. Moscow, Tip. V. V. Islen'eva Publ., 1887. 510 p.).

4. McClelland J. S. The crowd and the mob: From Plato to Canetti. London, Boston, Unwin Hyman, 1989. 343 p.

5. Sighele S. La foule criminelle: Essai de psychologie collective (Russ. ed.: Sigele S. Prestupnaya tolpa. Opyt kollektivnoi psikhologii. St. Petersburg, Izd. F. Pavlenkova Publ., 1893. 116 p.).

6. Gallini C. Scipio Sighele et la foule délinquante. Hermes, 1988, no. 2, pp. 105-133.

7. Bon G., Le. Psychologie des foules (Russ. ed.: Lebon G. Psikhologiya narodov i mass. St. Petersburg, Izd. F. Pavlenkova Publ., 1896. 329 p.).

8. Tarde G. Les crimes des foules (Russ. ed.: Prestupleniya tolpy. Kazan, Tipo-lit, Imperial University Publ., 1893. 44 p.).

9. Rossi P. Les suggesteurs et la foule. Paris, A. Michalon, 1904. 222 p.

10. Ross E. A. The mob mind. Appletons' Popular Science Monthly, 1897, V. 51, no. 22, pp. 390-397. 
11. Gorbatov D. S., Bol'shakov S. N. Teorii tolpy v rossiiskoi psikhologicheskoi mysli kontsa XIX-nachalaXXvv. [The crowd theory in Russian psychological thought in the late 19th and early 20th century]. St. Petersburg, Art-Xpress Publ., 2015. 108 p.

12. Rubio V. Le regard sociologique sur la foule à la fin du XIX siècle. Mil neuf cent. Revue d'histoire intellectuelle, 2010, no. 1 (28), pp. 13-33.

13. Lazzeri C. La contagion des émotions entre psychologie sociale et sociologie, de Le Bon à Durkheim. Problemata: Revista Internacional de Filosofia, 2016, V. 7, no. 3, pp. 133-156. DOI: 10.7443/problemata.v7i3.32091

14. Chirkova E. V. Anatomiya finansovogo puzyrya [The anatomy of a financial bubble]. Moscow, Keis Publ., 2010. 416 p.

15. Frachette C. Le Médecin-Inspecteur Général Henri Fournial (1866-1932). Histoire des Sciences Médicales, 1986, V. 20, no. 4, pp. 381-390.

16. Fournial H. Essai sur la psychologie des foules: considérations médico-judiciaires sur les responsabilités collectives. Lyon, A. Storck; Paris, G. Masson, 1892.113 p.

17. Sighele S. Psychologie des sectes. Paris, V. Giard \& E. Brière, 1898. 231 p.

18. Barrows S. Miroirs déformants. Réflexions sur la foule en France à la fin du XIXe siècle. Paris, Aubier, 1990. 226 p.

19. Bellamy R. The advent of the masses and the making of the modern theory of democracy. In:T. Ball, R. Bellamy (eds.) The Cambridge history of twentiethcentury political thought. Cambridge: Cambridge University Press, 2003, pp. 70-103. DOI: $10.1017 / \mathrm{CHOL9780521563543.005}$

20. Tarde G. Les lois de l'imitation (Russ. ed.: Zakony podrazhaniya. St. Petersburg, Izd. F. Pavlenkova, 1892. 370 p.).

21. Sighele S. U'intelligenza della folla. Torino, F. Bocca, 1903. 166 p.

22. Tarde G. Foules et sectes au point de vue criminal. Revue des Deux Mondes. 1893, 15 novembre, pp. 349-387.

23. Voitolovskii L. Ocherki kollektivnoi psikhologii: v dvukh chastyakh. Ch. 2. Psikhologiya obshchestvennykh dvizhenii [Essays on collective psychology in two volumes. Volume 2: The psychology of social movements]. Moscow, Petrograd, Gos. izdatel'stvo Publ., 1925. 118 p.

24. Dobrovol'skii I. I. The psychology of criminal crowd. Russkaya mysl'-Russian Thought, 1894, Issue 12, pp. 130-158 (in Russian).

25. Cazanove F. Les femmes dans la foule: leur responsabilité criminelle. Bordeaux, Y. Cadoret, 1904. 120 p.

26. Sluchevskii V. K. The crowd and its psychology. Knizhki nedeli-Books of the Week, 1893, no. 5, pp. 5-23 (in Russian).

27. Shirkov V.P. Crimes of the crowd under the new criminal code: constructing responsibility. Zhurnal Ministerstva Yustitsii-Journal of the Ministry of Justice, 1904, no. 3, pp. 90-124 (in Russian). 
28. Blumer H. Collective behavior. In: New Outline of the Principles of Sociology. N. Y., Barnes \& Noble, 1951, pp. 167-221.

29. Brighenti A. M. La folla delinquente: Scipio Sighele, la psicologia delle folle e le origini della sociologia del XX secolo. Altre Storie, 2013, no. 41, pp. 16-18.

30. Reicher S. The psychology of crowd dynamics. In: M. A. Hogg, R. S. Tindale (eds.) Blackwell handbook of social psychology: Group processes. Oxford, Blackwell, 2001, pp. 182-208. DOI: 10.1002/9780470998458

31. Spears R., Postmes T. Group identity, social influence and collective action online: Extensions and applications of the SIDE model. In: S. S. Sundar (ed.) The handbook of the psychology of communication technology. Oxford, Wiley Blackwell, 2015, pp. 23-46. DOI: 10.1002/9781118426456

32. Drury J., Stott C. Contextualizing the crowd in contemporary social science. Contemporary Social Science, 2011, V. 6, Issue 3, pp. 275-288. DOI: 10.1080/21582041.2011.625626

33. Borch C. The exclusion of the crowd: The destiny of a sociological figure of the irrational. European Journal of Social Theory, 2006, V. 9, Issue 1, pp. 83-102. DOI: $10.1177 / 1368431006060464$ 